\title{
PERLINDUNGAN ANAK PIDANA DI LEMBAGA PEMBINAAN KHUSUS ANAK DALAM PERSPEKTIF MODEL PEMBINAAN ANAK SECARA PERORANGAN
}

\author{
Irma Cahyaningtyas \\ Fakultas Hukum Universitas Diponegoro Semarang \\ Jalan Prof. Soedarto, SH. Tembalang, Semarang \\ Email: irmacahyaningtyas@yahoo.com
}

\begin{abstract}
A child who didn't get affection they tend to be juvenile and consequence may be able to carry out deviate action which collide with regulation. These child must execute criminal process that will ended to a behavior treatment that will take place in The Juvenile Correction. One of the treatment that exist in The Juvenile Correction is the treatment that actually based to child. Those kind of treatment called the individual treatment model. This paper background by issues, firstly how individual treatment model implementation in The Juvenile Correction; second what kind of constraints which found in the individual treatment model in The Juvenile Correction. Research methods used were 1) juridical empirical method;2) socio legal approach;3)case study in The Juvenile Correction in Kutoarjo. Analysis concerning are explained, first individual treatment model was already known. There were the type of individual treatment model were both religiousness and counseling treatment. But, for implementation that model could not implement properly.
\end{abstract}

Keywords: Juvenile Deliquent, Juvenile Protection, Individual Treatment.

\begin{abstract}
Abstrak
Anak yang menjalani proses pidana yang berujung pada suatu pembinaan di bina di Lembaga Pembinaan Khusus Anak. Salah satu bentuk pembinaan yang ada adalah pembinaan yang bersumber pada individu anak, pembinaan itu disebut pembinaan anak secara perorangan. Tulisan ini didasari oleh suatu masalah yaitu pertama, bagaimana pelaksanaan model pembinaan secara perorangan di Lembaga Pembinaan Khusus Anak; kedua, kendala apa saja yang ditemui dalam pelaksanaan model pembinaan secara perorangan di Lembaga Pembinaan Khusus Anak. Metode Penelitian yang digunakan adalah 1) metode yuridis empirik; 2) pendekatan socio legal; 3) studi kasus pembinaan di Lembaga Pembinaan Khusus Anak Kutoarjo, Jawa Tengah. Analisis terhadap hasil penelitian ini mengungkapkan bahwa pertama, model pembinaan secara perorangan telah dikenal dan dilaksanakan di Lembaga Pembinaan Khusus Anak Kutoarjo. Bentuk dari model pembinaan tersebut adalah kegiatan pembinaan keagamaan dan konseling. Pada pelaksanaannya, model tersebut tidak dapat diterapkan dengan baik di Lembaga Pembinaan Khusus anak.
\end{abstract}

Kata Kunci: Anak Berkonflik Hukum, Perlindungan Anak, Pembinaan Anak Perorangan. 


\section{A. Pendahuluan}

Tujuan nasional Negara Republik Indonesia sebagaimana ditegaskan di dalam Pembukaan Undang-Undang Dasar Negara Repulik Indonesia Tahun 1945 adalah melindungi segenap bangsa Indonesia dan seluruh tumpah darah Indonesia dan untuk memajukan kesejahteraan umum, mencerdaskan kehidupan bangsa dan ikut melaksanakan ketertiban dunia yang berdasarkan kemerdekaan, perdamaian abadi dan keadilan sosial. Guna mewujudkan tujuan nasional tersebut maka perlu dilakukan upaya pembangunan nasional yang di dalamnya mencakup pembangunan manusia seutuhnya. Salah satu upaya pembangunan nasional tersebut adalah pembangunan di bidang hukum, terutama hukum pidana. Pembangunan hukum pidana di Indonesia diwujudkan melalui penegakan hukum pidana yang bekerja secara operasional melalui suatu sistem yang disebut Sistem Peradilan Pidana (Criminal Justice System).

Sebagai sebuah sistem, peradilan pidana memiliki perangkat atau sub-sistem yang seharusnya dapat bekerja secara simultan, koheren, koordinatif dan terintegrasi agar dapat berjalan efektif dan efisien. Di dalam sistem peradilan pidana terdapat beberapa sub-sistem seperti Kepolisian, Kejaksaan, Pengadilan, dan Lembaga Pemasyarakatan sebagai lembaga koreksi.

Lembaga Pemasyarakatan khusus bagi anak atau dikenal dengan nama Lembaga Pembinaan Khusus Anak mempunyai peran yang sangat besar dan strategis di dalam penegakan hukum pidana, yang semua itu dapat terwujud dalam pelaksanaan pembinaan bagi narapidana dan anak didik pemayarakatan. Pelaksanaan pembinaan inilah yang dikenal dengan pemasyarakatan.

Undang-Undang No.12 Tahun 1995 tentang Pemasyarakatan, Pasal 1 ayat 2 menegaskan bahwa :

“ Sistem Pemasyarakatan adalah suatu tatanan mengenai arah dan batas serta cara pembinaan Warga Binaan Pemasyarakatan berdasarkan Pancasila yang dilaksanakan secara terpadu antara pembina, yang dibina, dan masyarakat untuk meningkatkan kualitas Warga Binaan Pemasyarakatan agar menyadari keasalahan, memperbaiki diri, dan tidak mengulangi tindak pidana sehingga dapat diterima kembali oleh lingkungan masyarakat, dapat aktif berperan dalam pembangunan, dan dapat hidup secara wajar sebagai warga negara yang baik dan bertanggung jawab ".

Lahirnya sistem pemasyarakatan membawa Bangsa Indonesia memasuki era baru dalam pembinaan narapidana. Tujuan dari pembinaan narapidana adalah supaya setelah kembali ke masyarakat, narapidana tidak melakukan pelanggaran hukum lagi, serta dapat berperan aktif dan kreatif dalam pembangunan.

Narapidana dalam proses pemasyarakatan perlu diperhatikan hak-haknya dan perlu diberi perlindungan hukum. Terlebih lagi, jika narapidana itu masih dibawah umur dalam arti ia belum berusia 18 (delapan belas) tahun atau belum kawin, yang dalam pemasyarakatan disebut sebagai anak pidana. 
Konsideran Undang-Undang No.23 Tahun 2002 jo Undang-Undang Nomor 35 Tahun 2014 tentang Perlindungan Anak pada butir c dan d menyebutkan bahwa setiap anak kelak mampu memikul tanggung jawab melangsungkan eksistensi bangsa dan negara pada masa depan, maka anak perlu mendapat kesempatan yang seluas-luasnya untuk tumbuh dan berkembang secara optimal, baik fisik, mental mapun sosial, dan berakhlak mulia, perlu dilakukan upaya perlindungan serta untuk mewujudkan kesejahteraan anak dengan memberikan jaminan terhadap pemenuhan hak-haknya serta adanya perlakukan tanpa diskriminasi. Oleh karena itu, kepentingan anak harus dilindungi, tidak terkecuali ketika seorang anak berada dalam Lembaga Pembinaan Khusus Anak.

Perlindungan anak merupakan tolak ukur peradaban masyarakat suatu bangsa, maka wajib diusahakan perlindungan anak demi kepentingan nusa dan bangsa. Kegiatan perlindungan anak merupakan suatu tindakan hukum oleh karena itu perlu jaminan hukum bagi kegiatan perlindungan anak tersebut. Kepastian hukum perlu diusahakan demi kelangsungan kegiatan perlindungan anak dan mencegah penyelewengan yang membawa akibat negatif yang tidak diinginkan dalam pelaksanaan kegiatan perlindungan anak. ${ }^{1}$

Perlindungan anak harus juga dilakukan terhadap anak yang mengalami masalah kelakuan (pelanggaran-pelanggaran usia muda), karena anak yang melakukan kejahatan bukan karena ia memiliki sifat jahat, tapi karena keadaan anak tersebut tidak stabil akibat keadaan yang datang dari anak itu sendiri maupun yang berasal dari dunia luar, yaitu lingkungan yang mengelilingi. ${ }^{2}$ Keberadaan anak memberikan peran, tugas dan tanggung jawab kepada lembaga untuk melakukan upaya pembinaan anak nakal sebagai narapidana anak, hal tersebut seharusnya mempunyai dua unsur, yaitu :

1. Unsur perubahan sikap, mental, dan perilaku anak ke arah yang lebih baik;

2. Unsur perubahan perspektif negatif masyarakat terhadap ex-napi anak dalam lingkungan pergaulannya.

Pembinaan yang seharusnya dilakukan oleh lembaga harus berorientasi kepada individu, dalam hal ini adalah anak pidana dan sosial, dalam hal ini adalah masyarakat.

Keadaan lapangan memberikan gambaran yaitu kondisi anak yang menghuni Lembaga Pembinaan Khusus Anak sangat banyak. Hal tersebut bisa dilihat sebagai berikut :

Tabel 1. Jumlah Anak Pidana

\begin{tabular}{|c|c|c|}
\hline No & Tahun & Jumlah Anak Pidana \\
\hline 1. & 2011 & 3046 \\
\hline 2. & 2012 & 3564 \\
\hline 3. & 2013 & 3516 \\
\hline 4. & 2014 & 2658 \\
\hline
\end{tabular}

Sumber: smslap.ditjenpas.go.id

Arif Gosita, Masalah Korban Kejahatan, Akademika Presindo, Jakarta, 1993, hlm. 222.

Loebby Loqman, Makalah Penataran Nasional Hukum Pidana dan Kriminologi UNDIP, Semarang, 1995, hlm. 1-2 
Anak tidak akan memperoleh perlindungan apabila harus bercampur dengan narapidana dewasa selain itu dapat mengakibatkan anak menjadi terganggu psikologis akibat traumatis yang mendalam dan akan mengakibatkan anak akan mendapat stigma negatif.

Berbicara mengenai pembinaan, wujud yang ideal sebenarnya adalah individualisasi pembinaan. Hal tersebut adalah berdasarkan ide dari pemasyarakatan itu sendiri yaitu model pembinaan anak perorangan (individual treatment model). Khusus bagi anak, hal tersebut sangat dituntut. Dengan perkataan lain, pembinaan yang ditujukan kepada anak harus bersumber pada kategori-kategori, antara lain jenis tindak pidana yang dilakukan oleh anak, umur anak, pendidikan anak, pelakunya sudah pernah melakukan tindak pidana atau belum, dan lain-lain. Disamping itu juga harus diperhatikan kebutuhan anak lainnya, misalnya diadakannya kegiatan konseling, paket kerja dengan maksud agar anak mempunyai bekal hidup yang dapat dipergunakan setelah ia selesai menjalankan hukumannya di Lembaga Pembinaan Khusus Anak.

Pembinaan secara perorangan yang dilakukan oleh Lembaga Pembinaan Khusus Anak berarti menjadikan lembaga sebagai tumpuan terakhir bagi pemulihan sikap dan sifat dari anak tersebut. Jadi, berdasarkan hal diatas, perlu diketahui bentuk dari pembinaan secara perorangan termasuk hal-hal yang berkaitan dengan pembinaan tersebut.

\section{B. Rumusan Permasalahan}

Permasalahan yang akan coba diangkat dari tulisan ini adalah

1). Bagaimana pelaksanaan model pembinaan secara perorangan di Lembaga Pembinaan Khusus Anak?

2). Kendala apa saja yang ditemui dalam pelaksanaan model pembinaan secara perorangan di Lembaga Pembinaan Khusus Anak?

\section{Pembahasan}

Tulisan ini diangkat dari hasil penelitian penulis yang dilakukan di Lembaga Pembinaan Khusus Anak Kutoarjo, Jawa Tengah. Penulis dalam pembahasan menggunakan pendekatan socio-legal sehingga pembahasan tidak hanya dilihat dari undang-undang atau ranah normatif saja akan tetapi juga dilihat berdasarkan kondisi empirik.

\section{Tinjauan Yuridis terhadap Perlindungan Anak Berkonflik Hukum di Lembaga Pembinaan Khusus Anak.}

Kenakalan anak atau remaja dapat merupakan suatu kejahatan anak atau remaja atau disebut pula dengan istilah juvenile delinquency.Juvenile berasal dari bahasa latinjuvenilis, artinya anak-anak, anak muda, ciri karakteristik pada masa muda, sifat-sifat khas pada periode remaja. Sedangkan delinquent berasal dari kata latin delinquere yang berarti terabaikan, mengabaikan; yang kemudian diperluas artinya menjadi jahat, a-sosial, kriminal, pelanggar 
aturan, pembuat ribut, pengacau, penteror, tidak dapat diperbaiki lagi, durjana, dursila, dan lain-lain. ${ }^{3}$

Maud A. Merril memberikan perumusan tentang juvenile delinquency, yaitu seorang anak digolongkan anak delinkuent apabila tampak adanya kecenderungan-kecenderungan anti sosial yang demikian memuncaknya sehingga yang berwajib terpaksa atau hendaknya mengambil tindakan terhadapnya, dalam arti menahannya atau mengasingkannya. ${ }^{4}$

Definisi anak dalam Rule 2.2 (a) The Beijing Rules,

"A juvenile is a child or young person who, under the respective legal system, may be dealt with for an offence in a manner which is different from adult" 5

(Juvenile adalah anak atau remaja yang menurut sistem hukum yang berlaku, telah melakukan kejahatan yang perlakuannya harus berbeda dengan perlakuan terhadap orang dewasa).

Undang- Undang No.11 Tahun 2012 tentang Sistem Peradilan Pidana Anak, memberikan definisi anak sebagai berikut :

- Pasal 1 butir 3, merumuskan bahwa anak yang berkonflik dengan hukum yang selanjutnya disebut anak adalah anak yang telah berumur 12 (dua belas) tahun, tetapi belum berumur 18 (delapan belas) tahun yang diduga melakukan tindak pidana.

- Pasal 1 butir 4, merumuskan anak yang menjadi korban tindak pidana yang selanjutnya disebut anak korban adalah anak yang belum berumur 18 (delapan belas) tahun yang mengalami penderitaan fisik, mental, dan/atau kerugian ekonomi yang disebabkan oleh tindak pidana.

- Pasal 1 butir 5 merumuskan bahwa anak yang menjadi saksi tindak pidana yang selanjutnya disebut sebagai anak saksi adalah anak yang belum berumur 18 (delapan belas) tahun yang dapat memberikan keterangan guna kepentingan penyidikan, penuntutan, dan pemeriksaan di sidang pengadilan tentang suatu perkara pidana yang didengar, diliat dan/atau dialaminya sendiri.

Dalam tulisan ini yang dimaksud anak adalah anak nakal (anak pidana) yang menjalani pembinaan di Lembaga Pembinaan Khusus Anak yang dalam prakteknya dikenal dengan sebutan anak didik pemasyarakatan. Anak pidana adalah anak yang berdasarkan putusan pengadilan menjalani pidana di Lembaga Pemasyarakatan Anak paling lama sampai berumur 18 (delapan belas) tahun. Pasal 20 Undang-Undang No. 12 Tahun 1995 tentang Pemasyarakatan menyebutkan pembinaan dilakukan berdasarkan umur, jenis kelamin, lama pidana yang dijatuhkan, jenis kejahatan, dan kriteria lainnya yang sesuai dengan kebutuhan atau perkembangan pembinaan. Anak pidana yang menjalani pembinaan harus diakui dan

Berkaitan dengan Lembaga Pembinaan Khusus Anak berarti berbicara mengenai sistem pemasyarakatan. Prof Sudarto menyebut istilah "pemasyarakatan" dapat disamakan dengan

3 Kartini Kartono, Kartono,Kenakalan Remaja Patologi Sosial 2, PT.Raja Grafindo Persada, Jakarta, 2008, hlm. 6.

4 Wagiati Soetodjo, Hukum Pidana Anak, Refika Aditama, Bandung, 2006, hlm. 10.

5 http :// www.un.org/document/ga/res/40/ SMR_JJ 
"resosialisasi" dan atau "rehabilitasi". Sistem pemasyarakatan menurut Baharudin Soerjobroto, tidak luput pula dari pengaruh yang negatif dari hukum kelambatan manusia dan dikalangan masyarakat luas, "pemasyarakatan" ini diidentikkan dengan "kepenjaraan" bukan saja mengenai ruang lingkup kegiatannya, akan tetapi juga tentang dasar pengertiannya. Dalam rangka prevention of crime ada dua aspek yang sangat menonjol dari sistem pemasyarakatan dalam fungsinya yakni :

a. Sebagai pembinaan dari pelaksanaan pidana (pidana penjara).

b. Sebagai pembinaan dari yang dikenakan pidana (pidana penjara). ${ }^{6}$

\section{Pelaksanaan Model Pembinaan Secara Perorangan di Lembaga Pembinaan Khusus Anak.}

Menurut Barda Nawawi Arief, inti tujuan pemidanaan dalam Konsep KUHP mengandung dua aspek, yaitu ${ }^{7}$ :

a. Aspek Perlindungan Masyarakat (Kepentingan Umum), khususnya :

- Pencegahan kejahatan,

- Pengamanan (pengayoman) masyarakat,

- Pemulihan keseimbangan masyarakat

- penyelesaian konflik (conflict opplossing) dan

- mendatangkan rasa damai (vredemaking)

b. Aspek Perlindungan (Pembinaan) Individu :

- Memasyarakatkan terpidana (resosialisasi/rehabilitasi)

- Membebaskan rasa bersalah

- Pemidanaan tidak dimaksudkan untuk menderitakan dan merendahkan martabat manusia (perlindungan terhadap sanksi yang sewenang-wenang/bersifat pembalasan).

Pembinaan yang dilakukan kepada pelaku kejahatan akan mengarahkan kepada proses resosialisasi dan rehabilitasi si pelaku sebagai tujuan dari dilaksanakannya pemidanaan. Hal tersebut perlu dilakukan karena pelaku dari kejahatan tidak dapat menyerap nilai-nilai sosial yang ada. Khusus bagi anak, hal tersebut menjadi suatu keharusan karena anak sebagai pelaku kejahatan memerlukan pembinaan lebih khusus daripada orang dewasa. Pembinaan itu dilakukan dengan usaha agar anak dapat menjadi lebih baik khususnya setelah ia kembali ke dalam masyarakat.

Anak sebagai individu yang melakukan suatu kejahatan, maka ia disebut orang yang menderita sakit, sakitnya individu tersebut dapat digolongkan oleh sakit fisik, sakit psikis, sakit sosial, dan sakit kultural. Untuk menghilangkan rasa sakit pada anak tentunya harus diobati dengan cara medik terapeutik dan diobati dengan cara pembinaan atau treatment secara perorangan atau individual.

6 R. Achmad S. Soemadi Praja dan Romli Atmasasmita, Sistem Pemasyarakatan di Indonesia, Percetakan Ekonomi, Bandung, 1992, hlm. 20.

7 Barda Nawawi Arief, Bahan Kuliah Politik Hukum Pidana, Magister Ilmu Hukum UNDIP. 
Gordon Bazemore mengetengahkan tiga paradigma peradilan anak yaitu a). Paradigma Pembinaan Individual, b). Paradigma Retributif, dan c). Paradigma Restoratif. ${ }^{8}$ Paradigma pembinaan perorangan atau individual treatment paradigm yang dikenal dengan model pembinaan yang dilakukan secara perorangan yang ditujukan untuk mengobati seseorang yang telah melakukan suatu kejahatan.

Model pembinaan perorangan menggambarkan bahwa persidangan anak berperan sebagai agensi quasi kesejahteraan dengan mandat peradilan, pembinaan anak pelaku delinkuen berlandaskan asumsi model medik, beranjak pada asumsi sebab-sebab delinkuensi anak. Delinkuensi dipandang sebagai gejala simptomatik. Hakekat dan seriusitas perilaku delinkuensi anak, tidak lebih, dilihat sebagai persoalan yang membutuhkan pelayanan terapitik dalam rangka mengobati gejala sakit pelaku delinkuen. ${ }^{9}$

Model yang dikenal di Eropa sebagai social welfare model ini memandang delinkuensi sebagai tanda gagalnya proses sosialisasi dan terlepas dari nilai-nilai substansial. Intervensi berupaya untuk memperbaiki perilaku delinkuensi lewat pemberian reaksi sesuai dengan personalitas dan kebutuhan anak pelaku delinkuen.

Sebenarnya model itu telah mendapat kritikan sebagai tidak adil dan tidak efektif sejak kehadirannya di tahun 1970-an. Ia digambarkan sebagai hal yang bersifat paternalistik, mahal, menimbulkan stigmatisasi dan tidak ada kepastian hukum. Walaupun demikian tampaknya asumsi pelaku delinkuen sebagai objek pasif yang membutuhkan pelayanan terapitik masih mendominasi praktek keseharian intervensi peradilan anak.

Pembinaan yang dilakukan berangkat dari satu dimensi saja, yaitu pelaku delinkuen bekerja atas dasar sistem logis yang tertutup, sebagai cenderung gagal untuk memasukkan pihak-pihak lain (korban dan masyarakat) dalam menanggapi delinkuensi lewat proses peradilan anak. Anak pelaku delinkuen cenderung berada dalam posisi pasif, kecuali kesempatannya untuk mengambil langkah aktif atas perilaku delinkuensi yang diperbuatnya atau langkah-langkah lain yang berorientasi pada upaya konsolidasi, rehabilitasi, reintegrasi. Pembinaan tidak mampu mempertemukan kepentingan pelaku, masyarakat, keluarga dan korban. ${ }^{10}$

Pembinaan yang diberikan kepada anak harus memperhatikan mengenai klasifikasi umur, latar belakang anak melakukan tindak pidana, berat ringannya perbuatan yang dilakukan, dan sebagainya. Hal tersebut agar anak sebagai penghuni tidak kehilangan haknya sebagai anak. Selain itu, di Lembaga Pembinaan Khusus Anak, anak juga mempunyai hak untuk memperoleh pendidikan dan latihan baik formal maupun informal sesuai dengan bakat dan kemampuannya, serta memperoleh hak-hak lainnya.

\footnotetext{
8 Gordon Bazemore, “Three Paradigms for Juvenile Justice” dalam Restorative Justice: International Perspective, Burt Galaway \& Joe Hudson (ed.), Kluger Publications, Amsterdam, 1996, hlm. 37.

9 Paulus Hadisuprapto, Pemberian Malu Reintegratif sebagai Sarana Nonpenal Penanggulangan Perilaku Delinkuensi Anak, Disertasi Program Doktor Ilmu Hukum Universitas Diponegoro, Semarang, 2002, hlm. 140.

10 Ibid, hlm. 144-145.
} 
Jadi dapat dikatakan Lembaga Pembinaan Khusus Anak adalah tempat terakhir yang sangat menentukan berhasil atau tidaknya pembinaan yang dilakukan terhadap anak. Berhasil berarti anak tersebut dapat berubah dan tentunya dapat diterima kembali dalam lingkungan masyarakat sedangkan tidak berhasil apabila anak tersebut tidak menunjukan perubahan sikap dan tingkah laku ketika ia telah selesai menjalani hukuman, akibatnya anak tersebut melakukan perbuatan yang melanggar undang-undang lagi.

\section{Bentuk Model Pembinaan Anak Individual atau Perorangan}

Pembinaan yang terdapat dalam Lembaga Pembinaan Khusus Anak Kutoarjo digolongkan menjadi dua, yaitu pembinaan secara umum dan pembinaan secara individual. Pembinaan secara umum dilakukan secara menyeluruh. Pembinaan tersebut dilakukan berdasarkan program yang sudah dibuat secara sistematis. Bentuk pembinaan secara umum tersebut adalah :

a. Pendidikan formal/ Kegiatan Belajar berupa Kelompok Belajar (Kejar)

Dalam rangka mencerdaskan kehidupan bangsa dan mensukseskan Program Pendidikan Dasar 9 (sembilan) tahun, Lembaga Pembinaan Khusus Anak Kutoarjo bekerjasama dengan Dinas Pendidikan Kabupaten Purworejo melalui Unit Pelaksana Teknis Dinas Sanggar Kegiatan Belajar (UPTD-SKB) Kabupaten Purworejo menyelenggarakan program kelompok belajar Paket A, Paket B, dan Paket C.

Pelaksanaan Kejar Paket A setara Sekolah Dasar (SD) belum dapat dilaksanakan karena jumlah siswa yang tidak memenuhi persyaratan. Untuk pelaksanaan Kejar Paket B setara Sekolah Menengah Pertama (SMP) sudah dilaksanakan dengan tenaga pengajar baik dari pihak Sanggar Kegiatan Belajar (SKB) maupun dari pihak Lembaga Pembinaan Khusus Anak Kutoarjo. Untuk pelaksanaan Kejar Paket C setara dengan Sekolah Menengah Atas (SMA) sudah dilaksanakan, bahkan sampai meluluskan siswanya.

b. Pendidikan non formal/ Pendidikan Keterampilan

Dalam usaha pemberian keterampilan bagi anak pidana, Lembaga Pembinaan Khusus Anak Kutoarjo bekerja sama dengan Dinas Tenaga Kerja melalui Balai Latihan Kerja (BLK) Purworejo dan Unit Pelaksana Teknis Dinas Sanggar Kegiatan Belajar (UPTD-SKB).

Bentuk keterampilan yang dilaksanakan di Lembaga Pembinaan Khusus Anak Kutoarjo, berupa :

- Pendidikan keterampilan pertukangan, sangkar burung;

- Pendidikan keterampilan pertanian;

- Pendidikan keterampilan peternakan ayam;

- Pendidikan keterampilan membuat mie ayam;

- Pendidikan keterampilan perbengkelan las;

- Pendidikan keterampilan wikel (gulung dinamo);

- Pendidikan keterampilan budidaya jamur tiram; 
- Pendidikan keterampilan pembuatan batako dan paving blok.

Pemenuhan hak untuk anak pidana yang didapat adalah mendapat pakaian; beribadah sesuai dengan agama yang dianut; mendapatkan makanan yang layak, bergizi, higienis; mendapat pengobatan kesehatan; mendapat pendidikan, baik pendidikan formal maupun non formal; berhak untuk dikunjungi orang tua;berhak untuk menyampaikan pendapat; berhak untuk cuti mengunjungi keluarga, dengan syarat setelah ia menjalani $1 \frac{1}{2}$ dari masa pidananya dan ia berkelakuan baik; berekreasi.

Pembinaan secara perorangan lebih ditujukan khususnya bagi pemulihan sikap dan mental dari anak didik.Pembinaan ini sangat penting karena terdapat berbagai macam sifat dari anak didik yang tentunya membutuhkan suatu pembinaan yang berbeda terutama pembinaan yang ditujukan untuk perbaikan diri anak didik itu sendiri. Bentuk dari pembinaan secara perorangan tersebut adalah sebagai berikut:

\section{a. Konseling}

Pembinaan ini lebih memperhatikan segala aspek yang bertujuan untuk perbaikan diri dari anak didik tersebut. Kegiatan lain yang merupakan program pembinaan secara perorangan adalah kegiatan yang disebut dengan perwalian. Dalam perwalian, disini pembina bertindak sebagai orang tua berhadapan langsung dengan anak. Seringkali muncul dalam diri anak pidana rasa kangen sehingga mereka mendatangi pembina untuk sekedar berbagi cerita. Dalam keadaan yang demikian, biasanya anak pidana menjadi seseorang yang perlu perhatian lebih, oleh karena itu dicari suatu jalan tengah yaitu pembina akan menghubungkan anak pidana tersebut dengan orang tuanya.

\section{b. Kegiatan keagamaan}

Unsur yang paling penting dalam pembinaan adalah agama. Tanpa bekal agama yang cukup, mustahil anak pidana dapat melanjutkan hidup di luar Lembaga Pembinaan Khusus Anak. Jadi, anak pidana juga harus memiliki bekal kegamaan disamping bekal keterampilan. Di Lembaga Pembinaan Khusus Anak Kutoarjo, kegiatan keagamaan sangatlah diutamakan. Kegiatan keagamaan mempunyai andil yang cukup besar. Dapat dikatakan anak pidana disini diposisikan sebagai orang yang sedang dalam keadaan sakit yang membutuhkan suatu tindakan. Apabila dalam keadaan sakitnya itu, diberikan siraman kerohanian maka ia akan dengan cepat sadar dan mengakui kesalahannya.

Menurut penulis, pembinaan secara perorangan yang dilakukan antara anak pidana dan pembina Lembaga Pembinaan Khusus Anak seyogyanya dilakukan dalam interaksi secara kekeluargaan. Hubungan yang terjalin antara pembina dengan anak pidana selayaknya orang tua dengan anaknya sendiri. Pembina diharapkan memberikan motivasi kepada anak pidana dan menempatkan diri sebagai orang tua dari anak pidana karena keadaan anak pidana yang jauh dari orang tua dan tidak adanya kemampuan untuk bertemu dengan orang tua. Jadi, dengan terjalinnya hubungan itu maka timbul suatu kewajiban yaitu anak pidana patuh terhadap pembina. 
Kegiatan pembinaan yang ditujukan kepada anak pidana adalah lebih kepada perbaikan sifat dan tingkah laku dari anak tersebut. Oleh karena itu, perlu dicari bentuk dari pembinaan yang ditujukan kepada anak pidana terutama program pembinaan yang dapat dengan cepat memberikan perubahan, respon atau nilai yang positif dari anak pidana. Dengan kata lain, menurut penulis, anak pidana harus dilibatkan dalam pelaksanaan pembinaan. Hal inilah yang perlu dilakukan oleh pembina agar dapat tercapai tujuan pembinaan anak, yaitu untuk mengubah sifat dan sikap anak menjadi lebih baik serta membina anak didik dengan memberikan keahlian atau ilmu sebagai bekal mereka nantinya. Pendapat tersebut adalah sesuai dengan konsep pemasyarakatan yang berupa resosialisasi dan bukan memberikan hukuman sebagai pembalasan atas perbuatan yang dilakukan

\section{Kendala-Kendala yang Ditemui dalam Pelaksanaan Metode Pembinaan Secara Perorangan}

Berbicara soal kendala dapat berarti dapat dikatakan metode tersebut kurang dapat diimplementasikan dengan baik di dalam Lembaga Pembinaan Khusus Anak. Memahami hukum sebagai suatu sistem terkait dengan pandangan Lawrence M. Friedman yang mengemukakan adanya komponen-komponen yang terkandung dalam hukum, yaitu: ${ }^{11}$

a. Komponen yang disebut dengan struktur. Ia adalah kelembagaan yang diciptakan oleh sistem hukum seperti pengadilan negeri, pengadilan administrasi yang mempunyai fungsi untuk mendukung bekerjanya sistem hukum itu sendiri. Komponen struktur ini memungkinkan pemberian pelayanan dan pengarapan hukum secara teratur.

b. Komponen substansi yaitu berupa norma-norma hukum, baik itu peraturan-peraturan, keputusan-keputusan dan sebagainya yang semuanya dipergunakan oleh para penegak hukum maupun oleh mereka yang diatur.

c. Komponen hukum yang bersifat kultural. Ia terdiri dari ide-ide, sikap-sikap, harapan dan pendapat tentang hukum. Kultur hukum ini dibedakan antara internal legal culture yakni kultur hukumnya lawyers dan judged's, dan external legalculture yakni kultur hukum masyarakat pada umumnya.

Teori sistem hukum ini dapat dipakai untuk menganalisis sistem yang telah berjalan di Lembaga Pembinaan Khusus Anak itu telah mendukung satu sama lain.

Menurut Bambang Poernomo, komponen sistem dalam pelaksanaan pidana penjara meliputi $:^{12}$

a. Narapidana;

b. Alat negara penegak hukum beserta masyarakat;

c. Lingkungan hidup sosial dengan segala aspeknya.

11 Lawrence M. Friedman, Sistem Hukum: Perspektif Ilmu Sosial (terjemahan), Nusa Media, Bandung, 2009, hlm. 15-18

12 Bambang Poernomo, Pelaksanaan Pidana Penjara Dengan Sistem Pemasyarakatan, Liberty, Yogyakarta, 1986, hlm. 94. 
Penggunaan model pembinaan secara perorangan sangat membutuhkan kualitas serta kuantitas. Hal tersebut tidak akan tercapai apabila salah satu pihak kurang memenuhi pengertian, bentuk, dan kualifikasi dari model pembinaan secara perorangan tersebut. Atas dasar itulah, berdasarkan pengamatan penulis ditemukan beberapa kendala yang secara langsung maupun tidak langsung berpengaruh terhahadap pelaksanaan metode pembinaan anak secara perorangan di dalam Lembaga Pembinaan Khusus Anak Kutoarjo.

Beberapa kendala tersebut dapat dijabarkan sebagai berikut :

a. Substansi

Substansi lebih mengarah kepada peraturan yang telah ada. Apakah peraturan perundang-undangan yang mengatur selama ini telah memenuhi hal-hal yang berkaitan dengan perlindungan anak, khususnya perlindungan anak pidana. Berdasarkan pengamatan penulis, seharusnya dengan adanya diversi yang sekarang ini telah digunakan sebagai upaya non- penal akan meminimalisir jumlah anak didik yang ada di Lembaga Pembinaan Khusus Anak seluruh Indonesia. Penerapan pidana haruslah digunakan sebagai upaya ultimum remedium mengingat bahaya stigma yang ditanggung oleh anak.

\section{b. Struktur}

Pembinaan anak secara perorangan atau individual memerlukan jumlah personil yang sangat banyak. Kondisi inilah yang tidak mungkin untuk diterapkan karena jumlah pembina yang ada tidak mencukupi untuk membina masing-masing anak didik. Selain jumlah pembina, pembinaan secara perorangan ini juga memerlukan banyak adanya peran serta dari psikolog, khususnya psikolog anak dan tokoh agama untuk memberikan bekal keagamaan pada anak didik. Aspek lain yang penting adalah kualitas dari pembina. Pembina yang berkualitas berarti harus sering mengikuti pendidikan khususnya untuk menangani masalah seputar anak nakal, oleh karena itu harus mempunyai dana yang lebih agar pembina dapat mendalami pendidikan yang mendaalm seputar masalah anak. Penggunaan model pembinaan anak secara perorangan jelas membutuhkan dana yang tidak sedikit. Pembinaan secara individual membutuhkan banyak fasilitas berupa sarana dan prasarana yang memang secara khusus disediakan untuk anak didik. Fasilitas tersebut adalah sebagaimana yang telah diamanatkan dalam United Nations Rules for The Protection of Juveniles Deprived of Their Liberty, misalnya sel yang dihuni secara individual, dalam arti terpisah satu anak pidana dengan anak pidana yang lain, kelas pendidikan, ruang pelatihan, ruang perpustakaan, dan lain-lain.

c. Kultur

Pemasyarakatan anak melibatkan para pihak, yaitu pembina, anak pidana, keluarga, dan masyarakat. Selama ini pembina terpaku pada pemikiran pembinaan yang dilakukan secara top-down. Pendekatan ini mewajibkan anak pidana untuk ikut serta dalam program pembinaan yang telah direncanakan oleh pembina sehingga unsur keamanan jauh lebih menonjol daripada unsur pembinaan. Seharusnya dilakukan pembinaan secara bottom-up, dimana pembinaan ini memperhatikan karakteristik inidividu. ${ }^{13}$ Menurut penulis, hal

13 Harsono CI, HS, Sistem Baru Pembinaan Narapidana, Djambatan, Jakarta, 1995, hlm. 20. 
inilah yang perlu disadari oleh pembina yang dapat dilakukan pertama-tama dengan mengubah mindset untuk membina anak karena disamping mereka adalah pelaku mereka juga korban. Peran serta pihak lain sangat dibutuhkan dalam upaya rehabilitasi dan resosialisasi anak pidana. Pihak pertama yang harus memberi dukungan adalah keluarga. Anak pidana di Lembaga Pembinaan Khusus Anak Kutoarjo ini kebanyakan jauh dari keluarga. Walaupun banyak diantara mereka yang sering dikunjungi oleh keluarga, akan tetapi tidak sedikit pula yang jarang dikunjungi oleh keluarga. Selain keluarga, pihak lain yang penting adalah masyarakat. Masyarakat juga perlu mengubah mindset bahwa mereka yang telah selesai menjalani pembinaan dalam Lembaga Pembinaan Khusus Anak harus diterima sebagai warga masyarakat yang utuh sama seperti mereka belum menjalani pembinaan di Lembaga Pembinaan Khusus Anak. Menurut penulis, hal tersebut harus didasari karena tidak semua anak pada kenyataannya dapat menghindari proses sistem peradilan pidana bahkan sampai ke tahap pemasyarakatan.

\section{Penutup}

Pembinaan anak secara perorangan telah dikenal dan dilakukan di Lembaga Pembinaan Khusus Anak. Pembinaan tersebut berupa pendidikan formal, pendidikan informal, konseling, dan kegiatan keagamaan. Keberhasilan pembinaan yang dilaksanakan terhadap anak pidana dapat tercapai apabila terjalin interaksi yang baik antara anak pidana sebagai pihak yang dibina, dengan pembina serta dukungan dari masing-masing pihak yang berkepentingan, yaitu keluarga, para pekerja profesional, serta masyarakat.

Pembinaan anak secara perorangan mempunyai indikator tertentu sehingga tujuan dari pembinaan yaitu resosialisasi dan rehabilitasi dapat tercapai. Akan tetapi dalam prakteknya, terdapat kendala yang menyebabkan pembinaan secara perorangan tidak dapat terlaksana dengan baik, walaupun secara yuridis pembinaan secara perorangan telah diatur secara sistematis dalam peraturan perundang-undangan yang ada. Beberapa kondisi tersebut diantaranya dari aspek substansi apakah peraturan perundang-undangan yang mengatur selama ini telah memenuhi hal-hal yang berkaitan dengan perlindungan anak, khususnya perlindungan anak pidana; aspek struktur, kualitas serta kuantitas dari pembina yang masih minim dalam memahami kondisi anak pidana; aspek kultur, pemasyarakatan anak melibatkan para pihak, yaitu pembina, anak pidana, keluarga, dan masyarakat. Para pihak terkait harus mengubah mindset dalam memberi perlakuan terhadap anak sebagai masyarakat yang utuh sama seperti mereka belum menjalani pembinaan di Lembaga Pembinaan Khusus Anak.

\section{Daftar Pustaka}

Arif Gosita, Masalah Korban Kejahatan, Akademika Presindo, Jakarta, 1993.

Bambang Poernomo, Pelaksanaan Pidana Penjara Dengan Sistem Pemasyarakatan, Liberty, Yogyakarta, 1986. 
Barda Nawawi Arief, Tujuan dan Pedoman Pemidanaan Perspektif Pembaharuan Hukum Pidana dan Perbandingan Beberapa Negara, Badan Penerbit Universitas Diponegoro, Semarang, 2009.

Bazemore, Gordon, "Three Paradigms for Juvenile Justice" dalam Restorative Justice: International Perspective, Burt Galaway \& Joe Hudson (ed.), Kluger Publications, Amsterdam, 1996.

CI, Harsono. HS, Sistem Baru Pembinaan Narapidana, Djambatan, Jakarta, 1995.

Friedman, Lawrence M, Sistem Hukum: Perspektif Ilmu Sosial (terjemahan), Nusa Media, Bandung, 2009.

Kartono, Kartoni, Kenakalan Remaja Patologi Sosial 2, PT.Raja Grafindo Persada, Jakarta, 2008.

Loebby Loqman, Makalah Penataran Nasional Hukum Pidana dan Kriminologi UNDIP, Semarang, 1995. , Bahan Kuliah Politik Hukum Pidana, Magister Ilmu Hukum UNDIP.

Paulus Hadisuprapto, Pemberian Malu Reintegratif sebagai Sarana Nonpenal Penanggulangan Perilaku Delinkuensi Anak, disertasi doktor, Semarang : Program Doktor Ilmu Hukum Universitas Diponegoro, 2002.

S. Soemadi Praja, R.Achmad dan Romli Atmasasmita, Sistem Pemasyarakatan di Indonesia, Percetakan Ekonomi, Bandung, 1992.

Wagiati Soetodjo, Hukum Pidana Anak, Refika Aditama, Bandung, 2006. 